\title{
THE GENERA OF EASTERN NORTH AMERICAN CHLOROPERLIDAE (PLECOPTERA): KEY TO LARVAL STAGES*
}

\author{
By SANDY B. FIANCE \\ Department of Entomology \\ Cornell University \\ Ithaca, New York 14853
}

Considerable changes in the systematics of North American chloroperlid stoneflies have resulted from the elevation of subgenera created by Ricker (1943) to generic status by Illies (1966) and Zwick (1973). Most significant are the new combination Rasvena terna, and the division of Alloperla (s. 1.) into five genera, only three of which occur in the region under study. Baumann (1974) separated the closely related species Alloperla imbecilla and A. atlanticum. Harper and Roy (1975) described the male of Utaperla gaspesiana, the first member of the Paraperlinae known from the Northeast, although Ricker (1952) found larvae from Tennessee that were referable to this subfamily. Hitchcock (1974) has summarized the status of members of the family found in Northeastern North America prior to 1971, and has provided species level keys for adults, but has retained the generic classification of Frison (1942).

At present, the family Chloroperlidae is represented in Eastern North America by 24 species in two subfamilies and six genera (Table 1). Larval stages are known only from four of these 24 species. This paper provides keys to genera of larvae needed because of nomenclatural changes and description of new species.

The larval stages of Suwallia marginata remain unknown. I have examined specimens of the Western North American species $\mathrm{Su}$ wallia pallidula. These may be separated from Sweltsa by the relatively fewer setae of the fore and hind femora, and on the eighth tergite, as well as the fewer long setae present on the apical corona of subterminal cercal segments.

*Manuscript received by the editor April 21, 1978. 
Separation of larvae to the specific level appears to be quite difficult, but may become possible by employing relative differences in the distribution of setae on the lateral surfaces of the head, dorsum of the legs, pronotum, eighth tergite, and mouthparts.

Table 1. Chloroperlidae of Eastern North America

\begin{tabular}{lc}
\hline PARAPERLINAE & \\
Utaperla gaspesiana & \\
CHLOROPERLINAE & \\
Alloperla & Hastaperla \\
atlanticum & brevis \\
banksi & orpha \\
caudata & Suwallia \\
chloris & marginata \\
concolor & Sweltsa \\
idei & lateralis \\
imbecilla & mediana \\
quadrata & nainina \\
leonarda & naica \\
neglecta & onkos \\
usa & urticae \\
voinae & Rasvena \\
vostocki & terna \\
\hline
\end{tabular}

\section{A KEY TO THE LARVAE OF \\ EASTERN NORTH AMERICAN CHLOROPERLIDAE}

1. Extensor surface of hind leg lacking a well developed fringe of fine, long setae (Fig. 1F); basal cercal segments having many long setae in apical corona, visible in lateral view (Fig. 1C) ... ........................... Utaperla gaspesiana

-. Hind tibia and often femur with a well developed fringe of long, fine setae on extensor surface (Fig. 2F); basal segments of cerci having few long setae in apical corona visible in lateral view (Fig. 2-5C) ..............................

2. Cerci with numerous long setae between apical coronas on distal segments forming a feather-like surface visible in lateral view (Fig. 2C); pronotum having few or no setae on front and hind margins, setae present only at corners (Fig. 2B); eighth tergite lacking setae at mesal posterior margin (Fig. 2D); integument yellow-gold ....................... Alloperla (s.s.) 


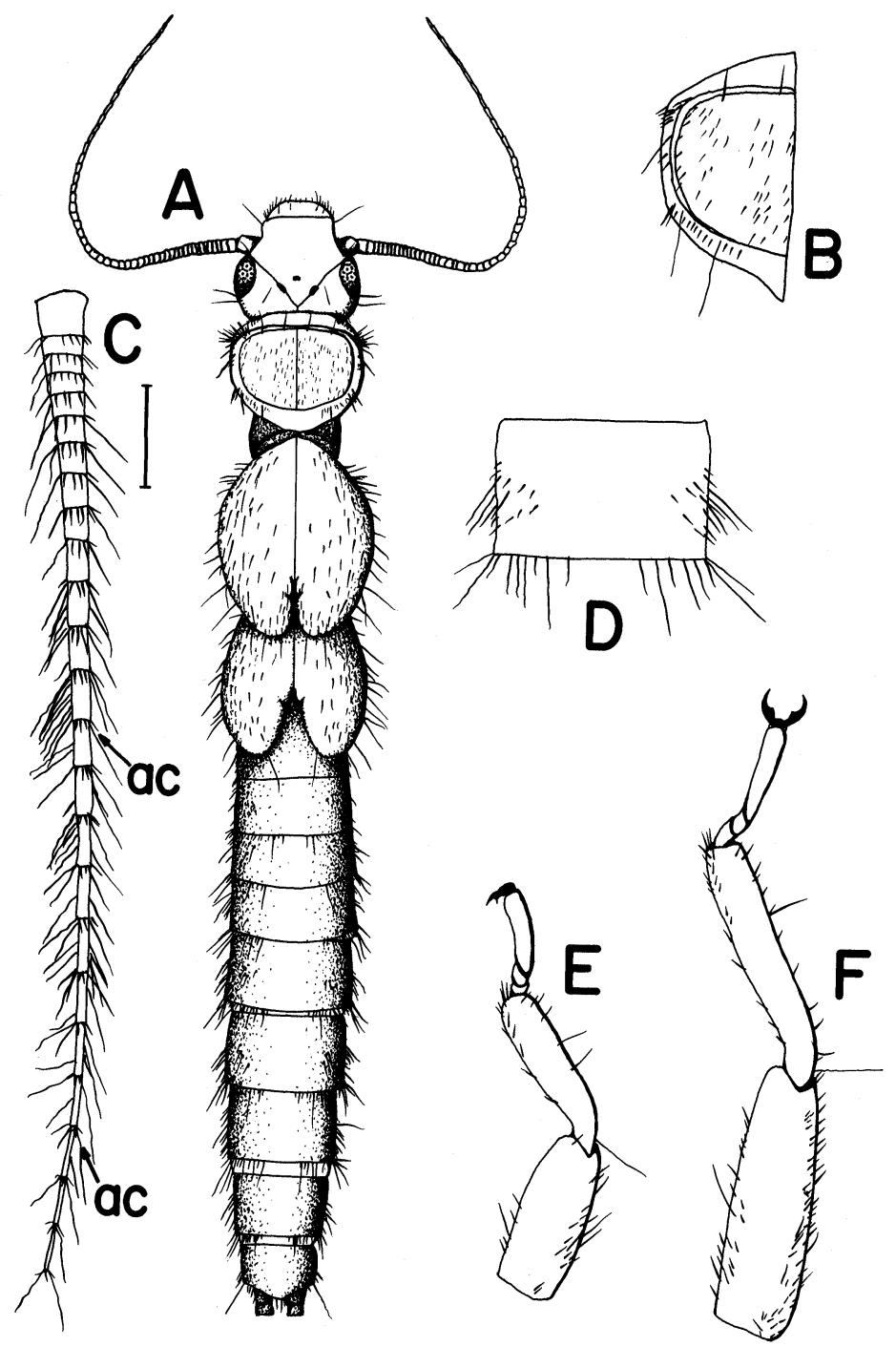

Figure 1. Utaperla gaspesiana. Mature larva, A. Habitus, B. Pronotum, C. Cercus, lateral view, D. Eighth tergite, E. Right foreleg, F. Right hindleg. New Hampshire, Grafton Co., W. Thornton, Pemigewasset River, 14 May, 1976, S. B. Fiance. (Scale: vertical bar $=\mathrm{A}-1 \mathrm{~mm}, \mathrm{~B}-\mathrm{F}-.5 \mathrm{~mm}$; ac $=$ apical corona.) 


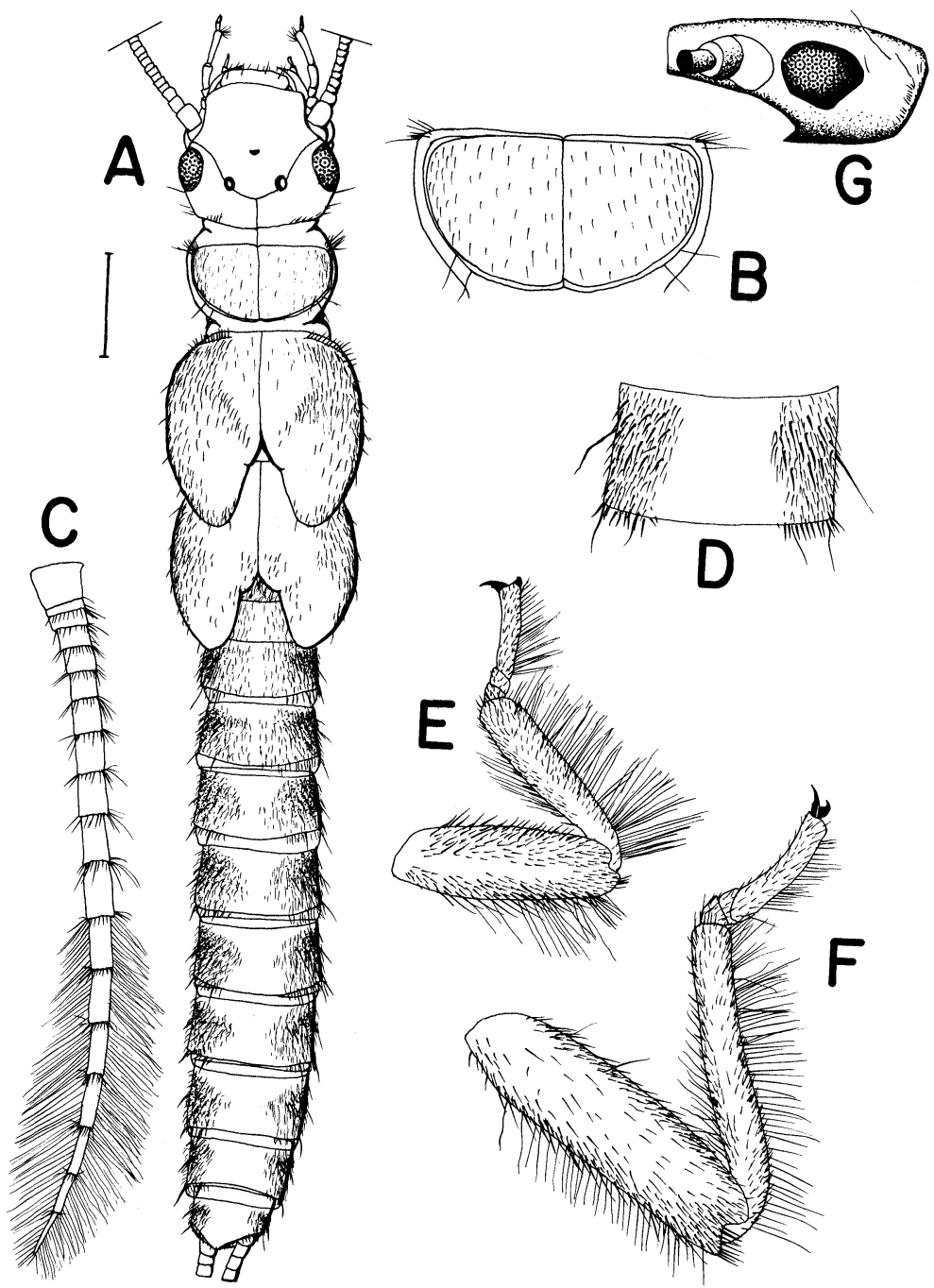

Figure 2. Alloperla concolor. Mature larva, A. Habitus, B. Pronotum, C. Cercus, lateral view, D. Eighth tergite, E. Right foreleg, F. Right hindleg, G. Left lateral view of head. New Hampshire, Grafton Co., W. Thornton, Hubbard Brook, 26 May, 1975, S. B. Fiance. (Scale: vertical bar $=\mathrm{A}-1 \mathrm{~mm}, \mathrm{~B}-\mathrm{G}-.5 \mathrm{~mm}$.) 


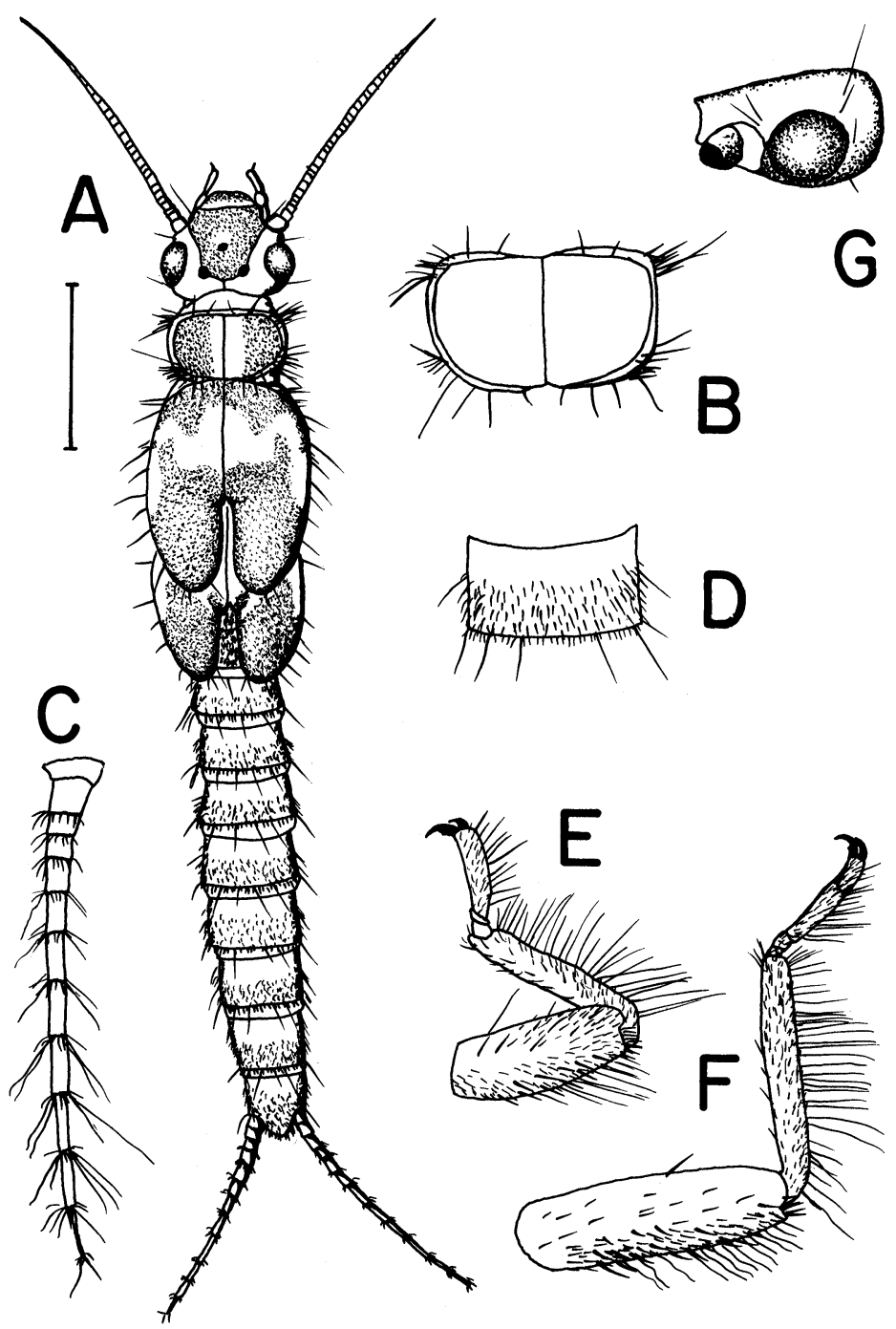

Figure 3. Hastaperla brevis. Mature larva, A. Habitus, B. Pronotum, C. Cercus, lateral view, D. Eighth tergite, E. Right foreleg, F. Right hindleg, G. Left lateral view of head. New Hampshire, Grafton Co., W. Thornton, Hubbard Brook, 5 June, 1975, S. B. Fiance. 


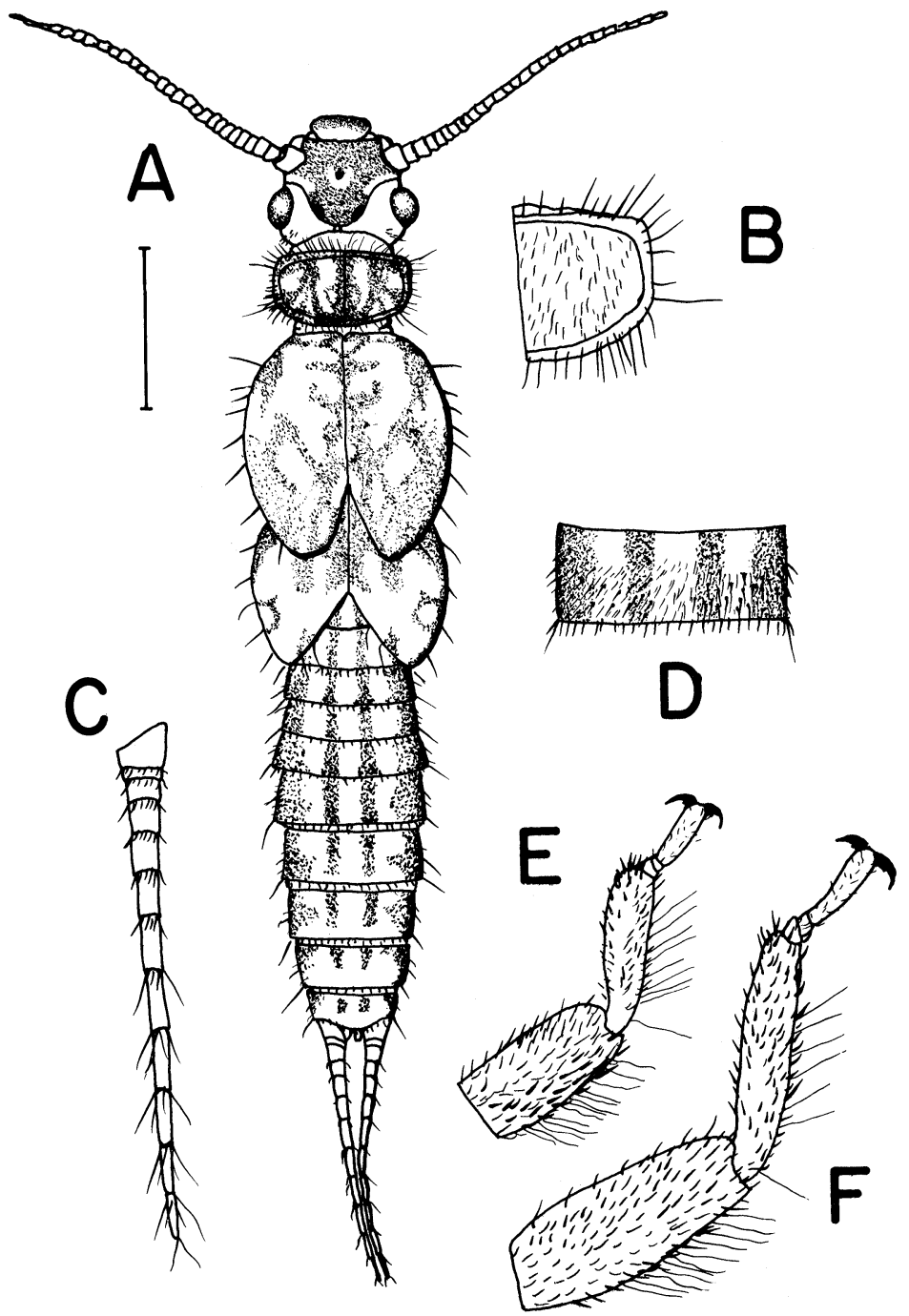

Figure 4. Rasvena terna. Mature larva, A. Habitus, B. Pronotum, C. Cercus, lateral view, D. Eighth tergite, E. Right foreleg, F. Right hindleg. New Hampshire, Grafton Co., W. Thornton, Pemigewasset River, 28 May, 1975, S. B. Fiance. 


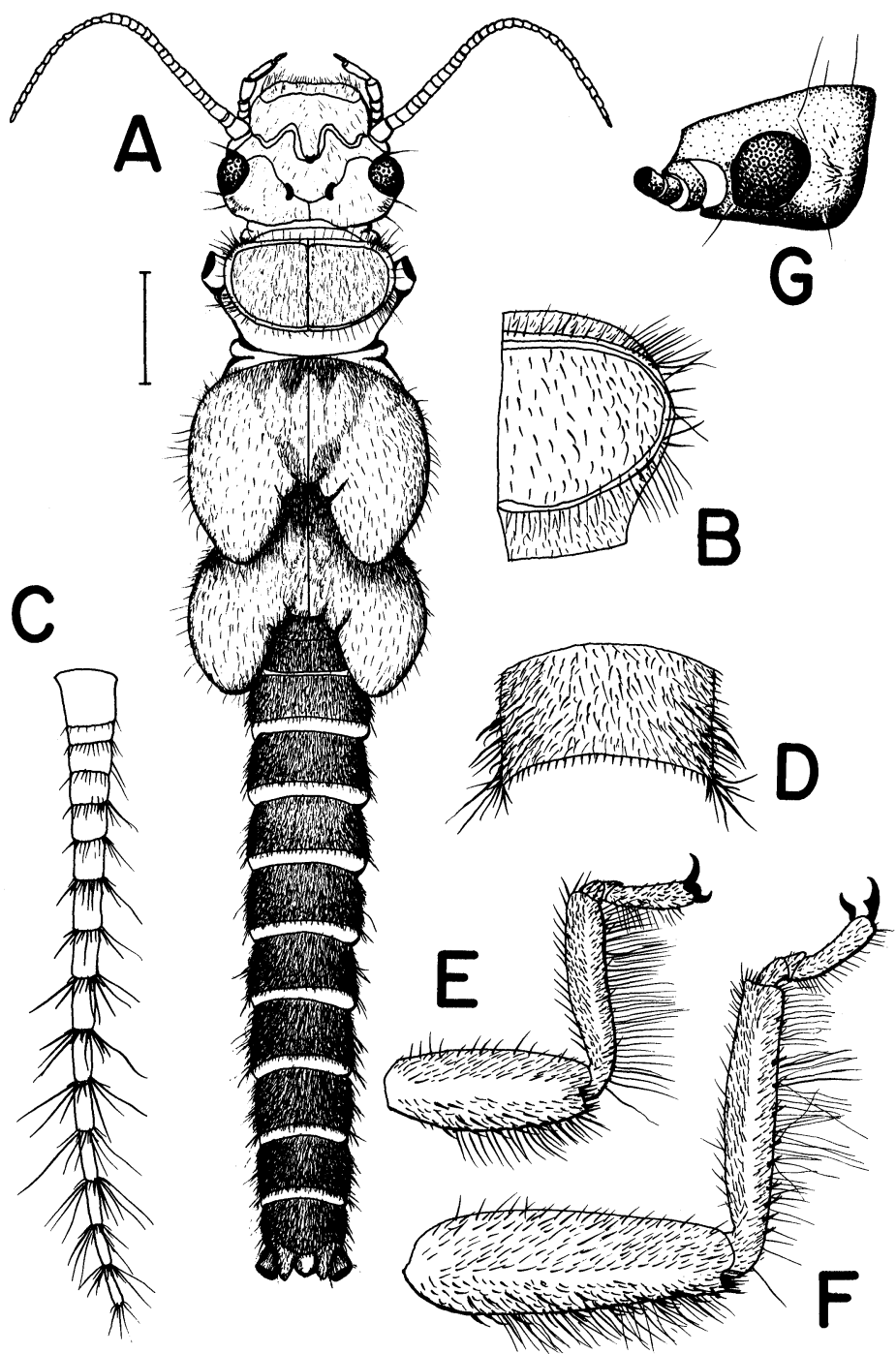

Figure 5. Sweltsa onkos. Mature larva, A. Habitus, B. Pronotum, C. Cercus, lateral view, D. Eighth tergite, E. Right foreleg, F. Right hindleg, G. Left lateral view of head. New Hampshire, Grafton Co., W. Thornton, Bear Brook, 1 June, 1974, S. B. Fiance. 
-. Cerci entirely lacking or with scattered long setae between apical coronas (Fig. 3-5C); pronotum with setae on posterior margin and usually on anterior margin as well (Fig. 3-5B); setae present on entire posterior margin of eighth tergite (Fig. 3-5D); integument gold-brown $\ldots \ldots \ldots \ldots \ldots \ldots \ldots \ldots \ldots \ldots \ldots \ldots$

3. Inner margin of hind wing pads parallel to body axis (Fig. 3A); less than 6 short, coarse setae between compound eye and hind margin of head (Fig. 3G); abdominal tergites lightly setose; pronotum having only sparse, fine setae on dorsal surface .......

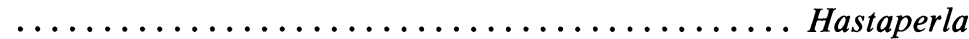

-. Inner margin of hind wing pads angled away from body axis (Fig. 4A); greater than 6 short, coarse setae between eye and hind margin of head (Fig. 5G); abdominal tergites heavily setose; pronotum with coarse, closely appressed setae on dorsal surface (Fig. 4-5B) .............................

4. Dorsum of abdomen unicolorous except when adult coloration shows through; eighth abdominal tergite with setae absent from a proximal band at most $1 / 5$ the length of the tergite (Fig. 5D) ........................................ Suwallia

-. Dorsum of abdomen with longitudinal dark stripes in mature larvae; setae absent from a band comprising the proximal $1 / 4$ to $1 / 3$ of the eighth tergite (Fig. 4D)........ Rasvena terna

\section{ACKNOWLEDGEMENTS}

The author would like to thank Dr. W. L. Brown, Jr., Cornell Univ., for his critical reading of the manuscript. The Grace Griswold Fund has generously provided funding for publication costs.

\section{Literature Cited}

BAUMANN, R. W.

1974. What is Alloperla imbecilla (Say)? Designation of a neotype, and a new Alloperla from Eastern North America (Plecoptera: Chloroperlidae). Proc. Biol. Soc. Washington 87: 257-264.

FRISON, T. H.

1942. Studies of North American Plecoptera, with special reference to the fauna of Illinois. Bull. Illinois Nat. Hist. Surv., Urbana 22: 235-355.

HARPER, P. P. AND D. ROY

1975. Utaperla gaspesiana sp. nov., le premier Plécoptère Paraperlinaé de l'est Canadien. Can. J. Zool. 53: 1185-1187. 
Нітснсоск, S. W.

1974. Guide to the insects of Connecticut. Part VII. The Plecoptera or stoneflies of Connecticut. St. Geol. Nat. Hist. Surv. Conn., Bull. 107: $1-262$.

ILLIES, J.

1966. Katalog der rezenten Plecoptera. Das Tierreich, Berlin 82: I-XXX; $1-632$.

RICKER, W. E.

1943. Stoneflies of Southwestern British Columbia. Indiana Univ. Publ., Sci. Ser., Bloomington 18: 1-200.

Zwick, P.

1973. Insecta: Plecoptera. Phylogenetisches System und Katalog. Das Tierreich, Berlin 94: I-XXXII; 1-465. 

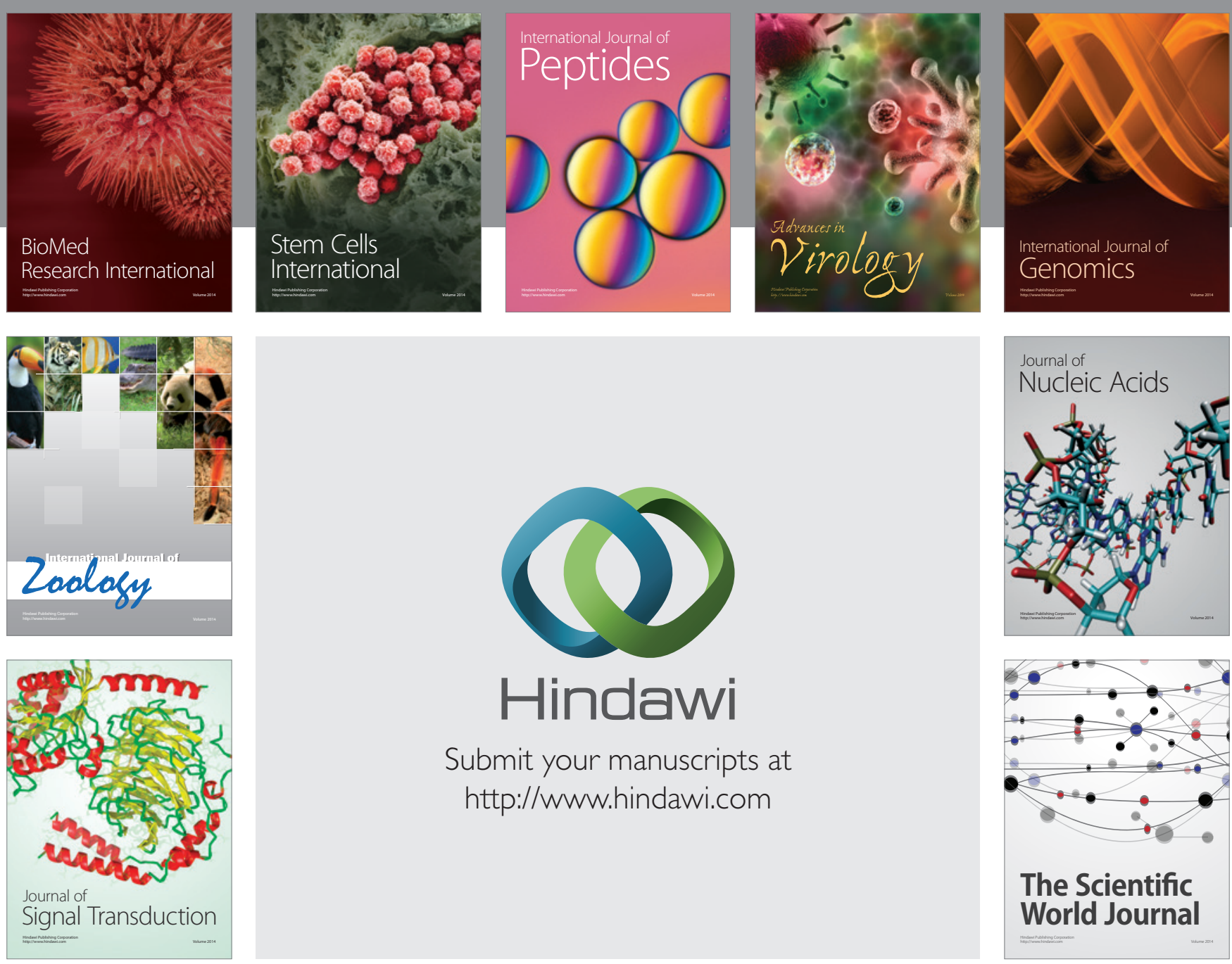

Submit your manuscripts at

http://www.hindawi.com
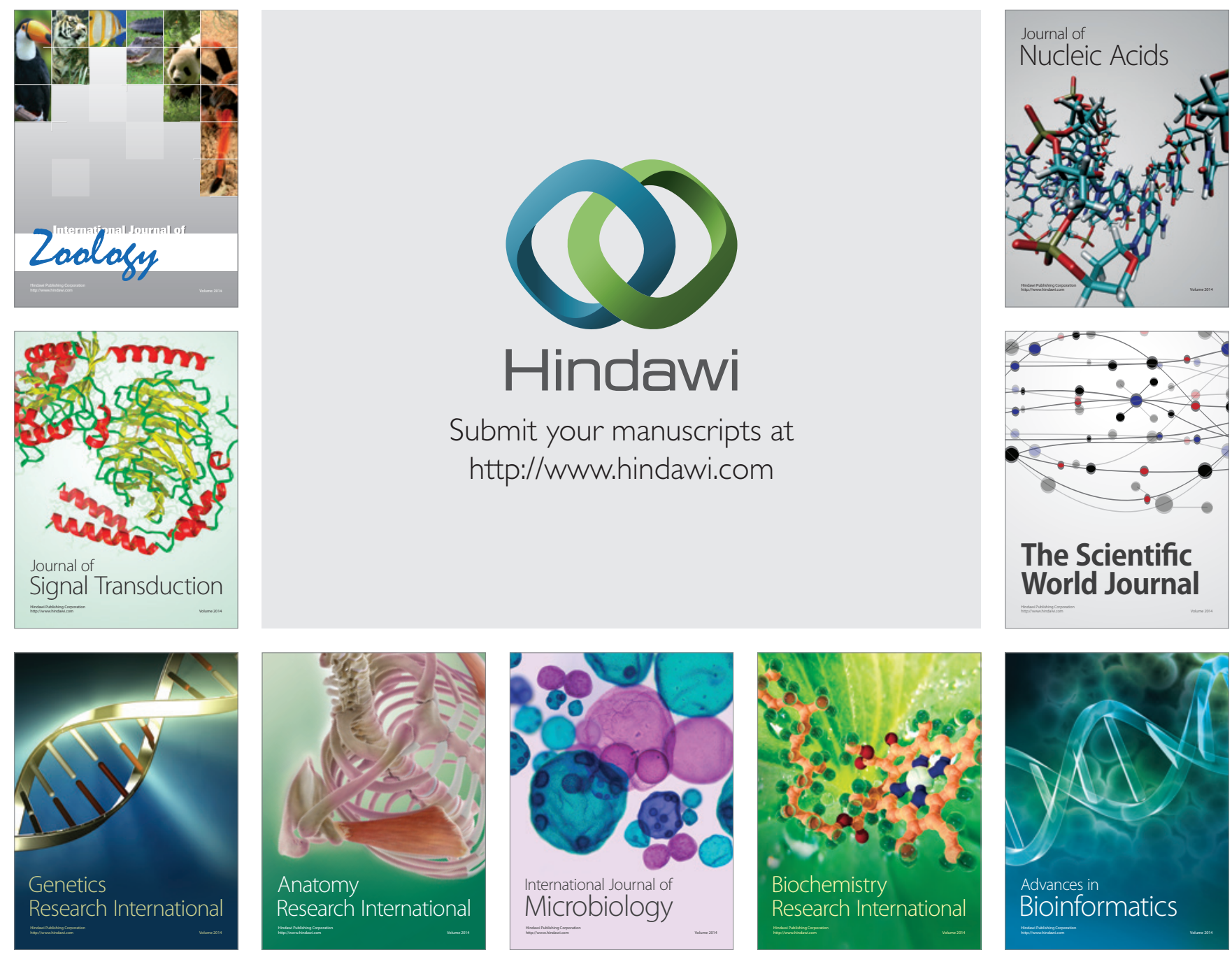

The Scientific World Journal
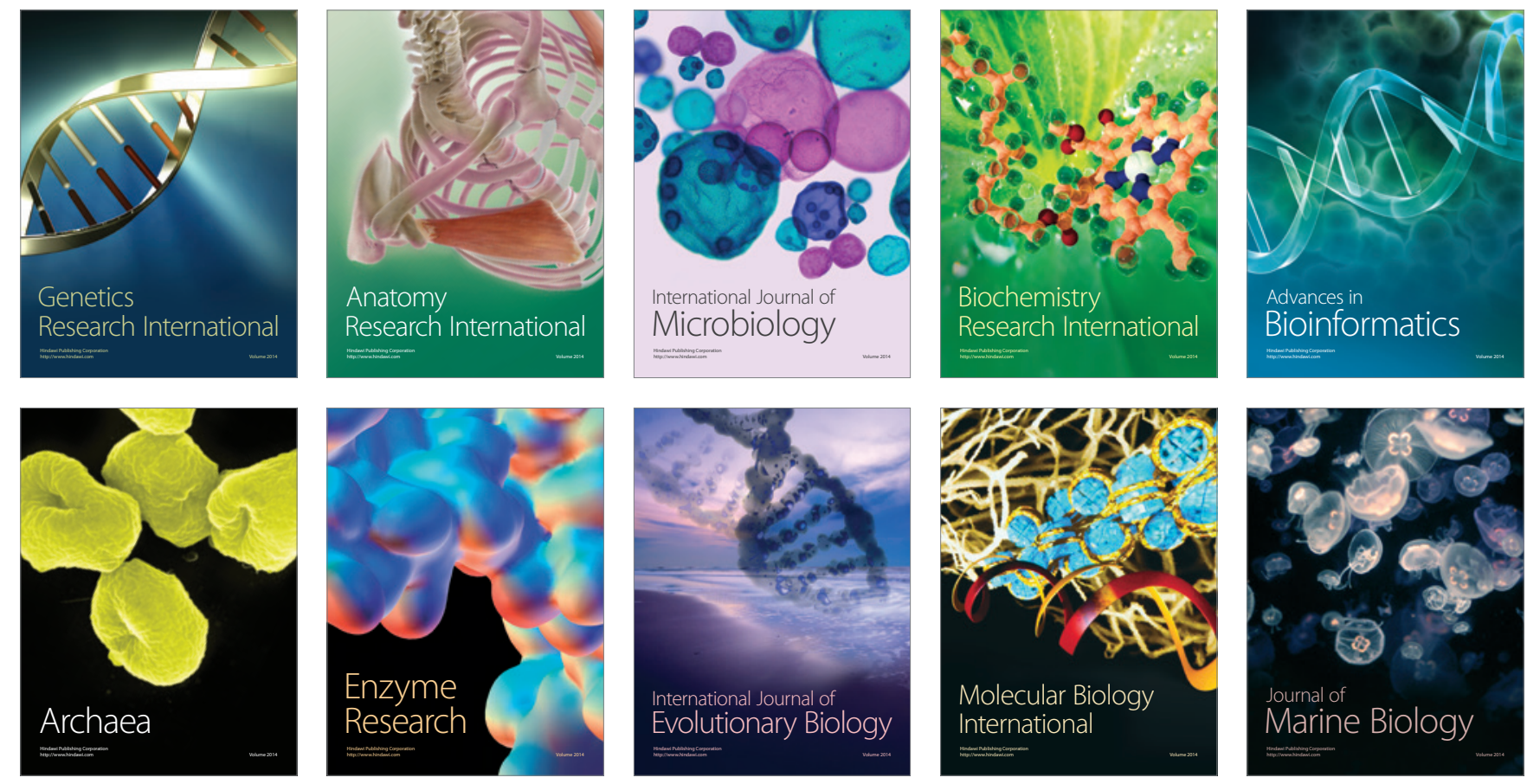